\title{
Peningkatan Pengetahuan Remaja dalam Upaya Pencegahan Penyakit Menular Seksual di Desa Jagaraga Kuripan Lombok Barat
}

\author{
Irni Setyawati ${ }^{1, *}$, Dian Soekmawaty Riezqy Ariendha ${ }^{1}$, Kusniyati \\ Utami $^{1}$, Zaenal Arifin' ${ }^{1}$, Sri Handayani ${ }^{1}$ \\ aSTIKes Yarsi Mataram, Jl. TGH Muh. Rais Lingkar Selatan Mataram, \\ Indonesia 83361 \\ Email Korespondensi: erny.gunawan07@gmail.com
}

Diterima: Mey 2021; Revisi: Juni 2021; Diterbitkan: Juni 2021

\begin{abstract}
This service aims to increase the knowledge of adolescents about efforts to prevent sexually transmitted diseases in Jagaraga village. The method of service is counseling with an educative approach through stages (i) Pretest (ii) Health education about sexually transmitted diseases (iii) Health education about HIV/AIDS (iv) Health education about healthy sexual behavior (v) Evaluation. This activity was carried out for 4 months (October 2019-January 2020). After a series of health counseling activities were carried out, there was an increase in the level of knowledge of adolescents after three times health counseling, namely an increase in the level of sufficient knowledge by $45.3 \%$ and a good level of knowledge by $21.4 \%$. It is hoped that the youth leaders and the Jagaraga village apparatus can follow up on this activity independently.
\end{abstract}

Keywords: STDs, HIV AIDS, sexual behavior

\begin{abstract}
Abstrak
Pengabdian ini bertujuan untuk meningkatkan pengetahuan remaja tentang upaya pencegahan penyakit menular seksual di desa Jagaraga. Adapun metode pengabdiannya yaitu penyuluhan dengan pendekatan edukatif melalui tahap (i) Pretes (ii) Penyuluhan kesehatan tentang penyakit menular seksual (iii) Penyuluhan kesehatan tentang HIV/AIDS (iv) Penyuluhan kesehatan tentang perilaku seksual yang sehat (v) Evaluasi. Kegiatan ini dilakukan selama 4 bulan (Oktober 2019-Januari 2020). Setelah dilakukan rangkaian kegiatan penyuluhan kesehatan, terjadi peningkatan tingkat pengetahuan remaja setelah dilakukan penyuluhan kesehatan selama tiga kali yaitu peningkatan tingkat pengetahuan cukup sebanyak 45,3\% dan tingkat pengetahuan baik sebanyak 21,4\%. Diharapkan ketua remaja dan perangkat desa Jagaraga dapat menindaklanjuti kegiatan ini secara mandiri.
\end{abstract}

Kata Kunci: PMS, HIV AIDS, perilaku seksual

How to Cite: Setyawati I., Ariendha R.S.D., Utami K., Arifin Z., Handayani S. (2021). Peningkatan pengetahuan remaja dalam upaya pencegahan penyakit menular seksual di desa Jagaraga Kuripan Lombok Barat. SASAMBO: Jurnal Abdimas (Journal of Community Service). 3(2), 70-75. DOI: 10.36312/sasambo.v3i2.468 


\section{LATAR BELAKANG}

Remaja adalah harapan bangsa, sehingga tidak berlebihan jika dikatakan bahwa masa depan bangsa yang akan datang ditentukan pada keadaan remaja saat ini. Remaja yang sehat dan berkualitas menjadi perhatian serius bagi orang tua, praktisi penyuluhan, ataupun remaja itu sendiri. Remaja yang sehat adalah remaja yang produktif dan kreatif sesuai dengan tahap perkembangannya. Remaja merupakan suatu masa transisi dari masa anak-anak ke masa dewasa. Remaja menurut definisinya adalah periode usia antara 10 sampai 24 tahun. Pada masa transisi ini, individu mulai mengembangkan ciri-ciri abstrak dan konsep diri menjadi lebih berbeda (Kusmiran, 2011).

Hasil survei penduduk antar sensus (Supas) 2015 menyebutkan jumlah penduduk Indonesia pada tahun 2019 diproyeksikan mencapai 266,91 juta jiwa yang terdiri atas 134 juta jiwa laki-laki dan 132,89 juta jiwa perempuan (Databoks, 2019). Hal ini menunjukkan bahwa jumlah remaja di Indonesia cukup besar. Desa Jagaraga merupakan salah satu desa di wilayah kecamatan Kuripan kabupaten Lombok Barat provinsi Nusa Tenggara Barat. Desa Jagaraga mempunyai 16,76\% penduduk berusia 1118 tahun yang merupakan tahap masa remaja.

Masa remaja merupakan masa transisi dimana remaja mencari jati diri dari lingkungan sekitarnya. Lingkungan sekitar remaja dapat memberikan dampak positif dan negatif. Salah satu dampak negatif yang banyak terjadi dialami remaja saat ini yaitu pergaulan bebas. Pergaulan bebas antara remaja laki-laki dan perempuan diawali dengan perasaan saling menyukai yang berujung pada perilaku seksual yang tidak sehat.

BKKBN, BPS dan Kementrian Kesehatan RI menemukan bahwa pada tahun 2017 91\% perempuan dari 207 orang dan 83,8\% laki-laki dari 231 orang di provinsi NTB pernah mendengar tentang HIV AIDS dan 23,7\% perempuan dan 32,5\% laki-laki pernah mendengar tentang penyakit menular seksual (BKKBN et al., 2017). BPS NTB menemukan bahwa pada tahun 2016 kabupaten Lombok Barat mempunyai kasus HIV sebesar 24\% dan kasus AIDS sebesar 22\% dari jumlah provinsi (BPSNTB, 2017).

Berdasarkan laporan kesehatan ibu dan anak Puskesmas Kuripan tahun 2019 telah ditemukan 15 kasus HIV yang 4 orang diantaranya telah meninggal dunia. Sebagian besar penderita adalah sebagai ibu rumah tangga. Tenaga kesehatan di Puskesmas Kuripan belum pernah memberikan penyuluhan kesehatan tentang penyakit menular seksual pada tahun 2019 karena terkendala jumlah tenaga kesehatan yang masih kurang, ketersediaan dana dan waktu pelaksanaan.

Berdasarkan laporan kesehatan ibu dan anak Puskesmas Kuripan tahun 2019 telah ditemukan 15 kasus HIV yang 4 orang diantaranya telah meninggal dunia. Sebagian besar penderita adalah sebagai ibu rumah tangga. Tenaga kesehatan di Puskesmas Kuripan belum pernah memberikan penyuluhan kesehatan tentang penyakit menular seksual pada tahun 2019 karena terkendala jumlah tenaga kesehatan yang masih kurang, ketersediaan dana dan waktu pelaksanaan. Masalah yang teridentifikasi diantaranya yaitu remaja belum memiliki pengetahuan yang memadai tentang penyakit menular seksual, Puskesmas setempat belum pernah memberikan pengetahuan yang memadai tentang penyakit menular seksual pada remaja dan pihak desa belum pernah menjalin kerjasama dengan institusi penyuluhan kesehatan untuk meningkatkan pengetahuan 
remaja yang memadai tentang penyakit menular seksual. Untuk mengatasi masalah di atas perlu dilakukan kerjasama kemitraan antara Desa Jagaraga dan STIKes Yarsi Mataram berupa pengabdian kepada masyarakat yang bertujuan untuk meningkatkan pengetahuan remaja desa Jagaraga Kuripan Lombok Barat tentang upaya pencegahan penyakit menular seksual. Peningkatan pengetahuan remaja ini diharapkan dapat merubah perilaku remaja dalam mengurangi atau bahkan mencegah kejadian penyakit menular seksual di desa Jagaraga.

\section{METODE PELAKSANAAN}

Mitra pengabdian kepada masyarakat ini yaitu Kepala Desa Jagaraga Kuripan kabupaten Lombok Barat yang mendiami kantor desa Jagaraga dengan jarak 12,3 km dari STIKes Yarsi Mataram. Mitra pengabdian berperan serta dalam memberikan ijin pelaksanaan pengabdian ini, menyiapkan ruangan dan waktu pada setiap pertemuan dan mengoordinir kehadiran remaja pada setiap pertemuan.

Kegiatan pengabdian kepada masyarakat ini merupakan kerjasama kemitraan yang diwujudkan dalam bentuk penyuluhan dengan pendekatan edukatif yang meliputi tahap (i) Pretes (ii) Penyuluhan kesehatan tentang penyakit menular seksual (iii) Penyuluhan kesehatan tentang HIV/AIDS (iv) Penyuluhan kesehatan tentang perilaku seksual yang sehat (v) Evaluasi yang diikuti oleh 42 orang remaja.

Pretes dilakukan pada pertemuan pertama yaitu untuk mengukur tingkat pengetahuan remaja tentang penyakit menular seksual, HIV AIDS dan perilaku seksual yang sehat. Pengukuran tingkat pengetahuan menggunakan kuesioner.

Penyuluhan kesehatan tentang penyakit menular seksual dilakukan pada pertemuan kedua dengan cara memberikan materi tentang penyakit menular seksual. Penyuluhan kesehatan tentang HIV AIDS dilakukan pada pertemuan ketiga. Pada pertemuan ini remaja diberikan materi tentang penyakit menular seksual. Penyuluhan kesehatan tentang perilaku seksual yang sehat dilakukan pada pertemuan keempat. Pada pertemuan ini remaja diberikan materi tentang perilaku seksual yang sehat. Penyuluhan kesehatan pada pengabdian ini menggunakan metode ceramah dengan alat bantu media power point yang dilengkapi gambar macam-macam penyakit menular seksual, HIV AIDS dan perilaku seksual yang sehat, diskusi tanya jawab interaktif juga disediakan setelah sesi ceramah.

Evaluasi tingkat pengetahuan remaja tentang penyakit menular seksual, HIV AIDS dan perilaku seksual yang sehat dilakukan pada akhir pertemuan. Evaluasi tingkat pengetahuan remaja diukur dengan menggunakan kuesioner yang sama pada saat pretes.

\section{HASIL DAN PEMBAHASAN}

Kegiatan pengabdian diawali dengan persiapan yang telah dilakukan pada tanggal 8 Oktober 2019 yaitu melakukan koordinasi dengan pihak kantor desa Jagaraga tentang tanggal pelaksanaan pretes, penyuluhan kesehatan dan evaluasi. Pretes tingkat pengetahuan remaja tentang penyakit menular seksual dilakukan pada pertemuan pertama. Kegiatan ini dilakukan di aula kantor desa Jagaraga pada tanggal 23 Oktober 2019. Kegiatan ini diisi oleh seluruh tim pengabdian kepada masyarakat. Adapun hasil tingkat pengetahuan remaja tentang PMS, HIV AIDS dan perilaku 
seksual yang sehat yaitu remaja yang berpengetahuan kurang sebanyak 66 kesehatan tentang penyakit menular seksual dilakukan pada pertemuan kedua. Pada pertemuan ini remaja diberikan materi tentang penyakit menular seksual. Kegiatan ini dilakukan pada tanggal 6 November 2019 diisi oleh tim pengabdian kepada masyarakat (gambar 1).

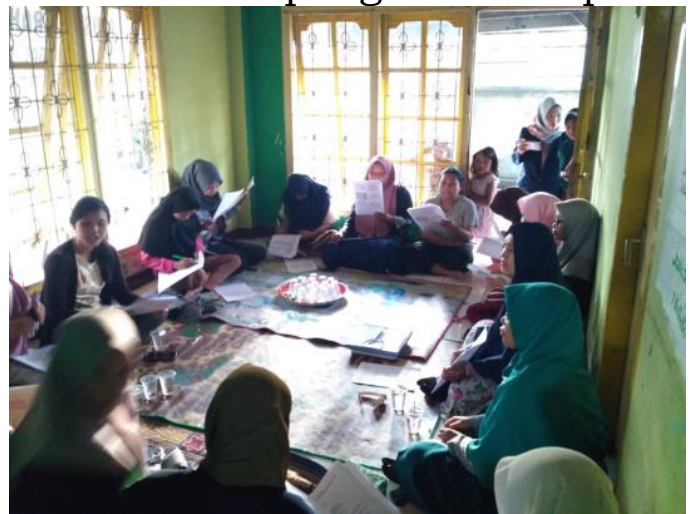

Gambar 1. Kegiatan penyuluhan kesehatan penyakit menular seksual

Penyuluhan kesehatan tentang HIV AIDS dilakukan pada pertemuan kedua. Pada pertemuan ini remaja diberikan materi tentang HIV AIDS. Kegiatan ini dilakukan pada tanggal 27 November 2019 diisi oleh tim pengabdian kepada masyarakat. Penyuluhan kesehatan tentang perilaku seksual yang sehat dilakukan pada pertemuan ketiga pada tanggal 11 Desember 2019. Kegiatan ini diisi oleh tim pengabdian kepada masyarakat (gambar 2).

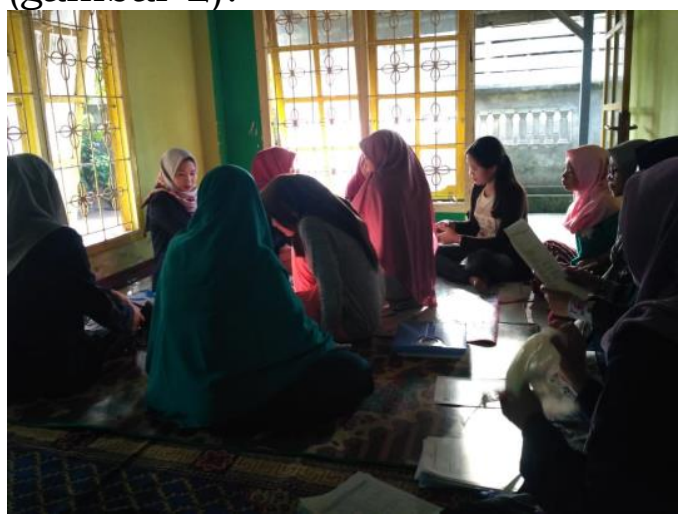

Gambar 2. Kegiatan penyuluhan kesehatan perilaku seksual yang sehat

Penyuluhan kesehatan reproduksi pada remaja dapat memberikan bekal pengetahuan kepada remaja mengenai berbagai permasalahan reproduksi untuk menyiapkan diri melaksanakan fungsi reproduksi yang sehat baik secara fisik, mental, ekonomi dan spiritual (Miswanto, 2014). Penyuluhan kesehatan adalah upaya pembelajaran kepada masyarakat agar terjadi perubahan perilaku untuk memelihara dan meningkatkan taraf kesehatannya (Notoatmodjo, 2012). Penyuluhan kesehatan yang dilakukan di desa Jagaraga ini menggunakan metode ceramah yang sangat efektif untuk remaja disertai diskusi interaktif antara tim pengabdian dan remaja.

Evaluasi tingkat pengetahuan remaja diukur dengan menggunakan kuesioner. Evaluasi tingkat pengetahuan sebagai hasil dari pemahaman remaja dilakukan pada tanggal 11 Januari 2020. Adapun hasil tingkat pengetahuan remaja tentang PMS, HIV AIDS dan perilaku seksual yang sehat yaitu remaja yang berpengetahuan cukup sebanyak $75,2 \%$ dan remaja yang berpengetahuan baik sebesar 24,8\%. Perubahan pengetahuan remaja ditunjukkan pada tabel di bawah ini: 
Tabel 1. Perubahan tingkat pengetahuan remaja tentang PMS, HIV-AIDS, dan perilaku seksual

\begin{tabular}{lcccccc}
\hline \multirow{2}{*}{\begin{tabular}{c} 
Kategori tingkat $\begin{array}{c}\text { pengetahuan } \\
\text { remaja }\end{array}$ \\
\cline { 2 - 7 } \multicolumn{1}{c}{$\begin{array}{c}\text { petes/sebelum } \\
\text { kesehatan }\end{array}$}
\end{tabular}} & $\begin{array}{c}\text { Presttes/setelah } \\
\text { penyuluhan } \\
\text { kesehatan }\end{array}$ & \multicolumn{2}{c}{ Peningkatan } \\
\hline Kurang & 28 & 66,7 & 0 & 0 & 14 & 33,3 \\
Cukup & 14 & 33,3 & 33 & 78,6 & 19 & 45,3 \\
Baik & 0 & 0 & 9 & 21,4 & 9 & 21,4 \\
\hline Total & 42 & 100 & 42 & 100 & 42 & 100 \\
\hline
\end{tabular}

Berdasarkan tabel 1 di atas dapat dilihat bahwa terjadi peningkatan tingkat pengetahuan remaja setelah dilakukan penyuluhan kesehatan selama tiga kali yaitu peningkatan tingkat pengetahuan cukup sebanyak $45,3 \%$ dan tingkat pengetahuan baik sebanyak 21,4\%. Hasil ini menunjukkan keefektifan penyuluhan kesehatan pada remaja yang telah dilaksanakan di desa Jagaraga dalam meningkatkan pengetahuan remaja.

Hasil pengabdian ini selaras dengan hasil penelitian Sulastri yang dilakukan pada remaja di desa Madureso yang menemukan bahwa terdapat perbedaan pengetahuan remaja secara bermakna antara sebelum dan sesudah diberikan penyuluhan kesehatan ( $p$ value 0,0001) (Sulastri \& Astuti, 2020). Demikian pula dengan penelitian Lutfi dan Suryati di SMPN 5 Banguntapan Bantul Yogyakarta yang memperoleh hasil ada pengaruh yang bermakna pada tingkat pengetahuan remaja antara sebelum dan sesudah dilakukan penyuluhan kesehatan $(\mathrm{p}<0,05)$ (Lutfi \& Suryati, 2019).

Pengetahuan merupakan hasil penginderaan manusia atau hasil dari tahu seseorang terhadap suatu objek dari indera yang dimilikinya. Pengetahuan seseorang dapat dipengaruhi oleh informasi yang diterimanya. Jika seseorang sering mendapatkan informasi tentang suatu materi maka akan menambah pengetahuannya (Notoatmodjo, 2014). Perubahan tingkat pengetahuan remaja yang ditunjukkan pada hasil pengabdian ini merupakan hasil dari proses memahami remaja terhadap materi yang telah diberikan.

\section{KESIMPULAN}

Kegiatan pengabdian kepada masyarakat "Peningkatan Pengetahuan Remaja dalam Upaya Pencegahan Penyakit Menular Seksual di Desa Jagaraga Kuripan Lombok Barat" dalam bentuk penyuluhan dengan pendekatan edukatif yang dilakukan oleh STIKES Yarsi Mataram telah meningkatkan pengetahuan remaja tentang PMS, HIV AIDS, dan perilaku seksual yang sehat pada tingkat pengetahuan cukup sebanyak 45,3\% dan tingkat pengetahuan baik sebanyak $21,4 \%$.

\section{REKOMENDASI}

Diharapkan ketua remaja dan perangkat desa Jagaraga dapat melakukan sosialisasi dan memonitoring perilaku seksual yang sehat secara terus menerus untuk mencegah kejadian PMS dan HIV AIDS, dan dapat memfasilitasi sarana dan prasarananya. 


\section{UCAPAN TERIMAKASIH}

Terima kasih disampaikan kepada Pusat Penelitian dan Pengabdian kepada Masyarakat STIKes Yarsi Mataram, Program Studi Kebidanan program Sarjana dan jenjang Diploma Tiga serta Kepala Desa Jagaraga beserta masyarakat desa Jagaraga sehingga kegiatan pengabdian kepada masyarakat ini terselenggara dengan baik.

\section{DAFTAR PUSTAKA}

BKKBN, Badan Pusat Statistik, Kementerian Kesehatan, \& IFC International. (2017). Survei Demografi dan Kesehatan Indonesia 2017. In Sdki.

BPSNTB. (2017). Kesehatan angka kejadian HIV AIDS sekabupaten kota provinsi NTB 2016. ntb.bps.go.id

Databoks. (2019). Jumlah penduduk Indonesia 2019 mencapai 267 juta jiwa. www.databoks.katadata.co.id

DinkesKabSidoarjo. (2014). Bagaimana cara penularan HIV? Dinkessidoarjokab.

http:/ / dinkes.sidoarjokab.go.id/2014/08/21/bagaimana-carapenularan-hiv/

KemenkesRI. (2016). Pedoman nasional penanganan infeksi menular seksual. Kemenkes RI.

KemenkesRI. (2017). Permenkes no. 21 tahun 2013 tentang penanggulangan HIV dan AIDS. KemhanRI.

Kora, F., Dasuki, D., \& Ismail, D. (2016). Pengetahuan tentang infeksi menular seksual dengan perilaku seksual tidak aman remaja putri maluku tenggara barat di daerah istimewa yogyakarta. Jurnal Kesehatan Reproduksi, 3(1), 50-59.

Kusmiran, E. (2011). Kesehatan reproduksi remaja dan wanita. Salemba Medika.

Lutfi, L., \& Suryati. (2019). Penyuluhan kesehatan meningkatkan pengetahuan remaja tentang seksualitas. Jurnal Keperawatan Respati Yogyakarta, 6(3), 654-658.

Miswanto. (2014). Pentingnya penyuluhan kesehatan reproduksi dan seksualitas pada remaja. Jurnal Studi Pemuda, 3(2), 111-121.

Notoatmodjo, S. (2012). Penyuluhan dan perilaku kesehatan. Rineka Cipta.

Notoatmodjo, S. (2014). Promosi kesehatan teori dan aplikasi. Rineka Cipta.

Sulastri, E., \& Astuti, D. P. (2020). Penyuluhan kesehatan untuk meningkatkan pengetahuan dan sikap remaja tentang kesehatan reproduksi dan penyakit menular seksual. Jurnal Ilmiah Kesehatan Keperawatan, 16(1), 93-102. 